\title{
The Development Of Literacy Reading Books of North Sumatera Fairy Tale For V Grade Students at Elementary School
}

\author{
Naomi Christina Nainggolan ${ }^{1}$, Rosliani $^{2}$ \\ 1Postgraduate in Indonesian Language and Literature Education, Universitas Prima Indonesia \\ ${ }^{2}$ Balai Bahasa Sumatera Utara \\ Email: naomichristinanainggolan@gmail.com, rosliani.12@gmail.com
}

\begin{abstract}
The purpose of this research is to develop a literacy reading books that contain North Sumatra myth to increase passion of reading in applying literacy program in school environment. The population is all of fifth grade students of SD Kalam Kudus-2 Medan in total 109 students, and the sample is class Mikha with 29 students. Sampling technique of the research is purposive sampling, which allow researcher to determine the sample with particular consideration. The research uses the development steps of Borg and Gall which are: (1) introduction survey, (2) product development, (3) product design, (4) design validation, (5) design improvement, and (6) final product. The result of the research indicates that it is really important to develop local myth reading books for teachers and students in implementing the literacy program. These books are validated by material and learning design expert teams. The presentation of validation result by material expert is in average $82,69 \%$ with good criteria, meanwhile by learning design expert is in average $87,94 \%$ with very good criteria. Result that shown of Bahasa Indonesia teachers is in average 98,9\% with very good criteria. In addition to small area test average is $91,66 \%$ with very good criteria. Overall, the limited area test result is in average $95 \%$ with very good criteria.

Keywords: reading books; North Sumatra myth; literacy; developing
\end{abstract}

\section{Introduction}

Reading is one of the most important functions in life. Reading is an essential and very important aspect in an effort to create a literate society, namely a society that is able to use reading to enrich spiritually and improve the quality of life. According to Palani (2012), reading is a process of identifying symbols and associating the right meaning with them. Texts provide symbols (meaning codes), while the reader translates the symbols or codes, so that there is a similarity between the ideas conveyed by the author and the meaning captured by the reader. Such a process requires practice to form what are known as reading habits. This reading habit will greatly affect the academic performance of students (Durgaiah, 2016) so that it is said that language is the defender of knowledge.

In the learning process, reading becomes the axis in gaining knowledge. When the ability to read becomes a culture in every child, the success rate at school and in community life will be even better. In this millennial era, reading habits have decreased. Based on the census of the Central Statistics Agency (BPS) in 2006, 85.9 percent of people chose to watch television instead of listening to the radio (40.3 percent) and read newspapers ( 23.5 percent). Indonesian people are not used to doing something based on understanding from reading. Indonesian people have not been able to actualize themselves through writing. Reading and writing have not become the culture and traditions of the Indonesian people. People are more familiar with visual media (watching), verbal (oral) or listening compared to reading, let alone writing. 
The above conditions are not only for the common people (the general public), in the environment of students and higher education, it is still far from what is called a good literacy culture. The younger generation has not yet planted a love for reading books, apart from being limited to reading status or the compulsion of a task. Even teachers and lecturers, not a few of them are the same. It is not difficult to identify in a more real way that Indonesian society does not yet have a good literacy tradition.

This low reading habit causes our human resources to be uncompetitive due to lack of mastery of science, as a result of weak reading and writing skills and interest. This is supported by the results of international research conducted by the Program for International Student Assessment (PISA). According to the results of the 2015 Program for International Student Assessment (PISA) survey, Indonesia's literacy score is only 403, while the global literacy rate is 493 .

The same thing was also expressed by UNESCO. According to UNESCO data in 2012 , the reading interest of the Indonesian people is very concerning, it is only $0.001 \%$. That means that out of a thousand Indonesians, only one person is truly diligent in reading.

Another research conducted by John W. Miller, president of Central Connecticut State University (CCSU) in New Britain entitled The World's Most Literate Nations (WMLN) ranked in March 2016, Indonesia was ranked 60th out of 61 countries regarding reading interest. Based on some of the studies mentioned above, it can be concluded that the ability to read has not become a national culture and has not been implanted as a necessity of life. It is clear that the number of libraries and books available is far from meeting the demands of reading as the basis of education.

\section{Review Literatures}

Dr. Roger Farr (1984) stated that "reading is the heart of education". In line with this, Dr. Ngainun Naim, in the book "Geliat Literasi (2015)" also wrote that to create the advancement of civilization in an area one of them is by developing literacy traditions. In this context, the younger generation who are also the generation of learners should be able to take an active role as a driving force for the advancement of a culture of literacy awareness in their respective environments to make it more massive.

According to Syakur (2020) the ability to understand reading is then closely related to the ability to listen or understand the script reading. Responding to this problem, the Ministry of Education and Culture through Ministerial regulation number 23 of 2013 issued a School Literacy Movement to foster noble character attitudes to children through language. Every child in primary school is required to read books before the learning process takes place. The realization of the literacy movement is not only up to the growth of interest in reading through 15 minutes of reading activities according to Permendikbud No. 23 of 2015. This is not the end goal. Teachers must understand that literacy development efforts do not stop when students can read fluently and have good reading interests as a result of habituating literacy culture. Literacy development needs to occur in learning in all subjects to optimize higher order thinking skills.

Mursyidi (2020) sstates that Indonesia has mandated the development of this education in the 1945 Constitution by prioritizing the protection of all Indonesian people. Primary school is a golden age, so it is important to instill noble values. The literacy 
movement is one way that can be done to instill noble character. Each school is expected to be able to carry out this promoted literacy movement so that the goals the government wants to achieve can be realized. However, when a field survey was conducted, namely the schools to be studied, it was found that the literacy movement was not really going well.

Seeing the unevenness in carrying out the literacy movement that is currently running at SD Kalam Kudus 2 Medan, it is evident that there is a lack of socialization of the literacy movement being promoted in schools. In this case, teachers are allowed to improvise in carrying out literacy. However, the Ministry of Education and Culture does not recommend that in literacy activities, the books used are subject books.

Based on the above problems, the researcher wants to develop books that are used in the literacy movement. This method is used by researchers as a strategy so that literacy can work. The strategy that the researchers used was the development of literacy reading books with North Sumatra fairy tales. The products produced through this development are reading books that are used as literacy materials for fifth grade elementary school children. This was done because he saw the problems that occurred in the field. The contents of the reading book are local fairy tales originating from North Sumatra.

This is done to build a noble personality, mentality, morality. The introduction of the wisdom of North Sumatra North Sumatra is expected to be a strength of the literacy culture of students so that it is not easily influenced by foreign cultures which are currently easily accessible to students. Researchers hope that the development of literacy books in schools will help improve student learning abilities. This is done to build a noble personality, mentality, morality. The introduction of the wisdom of North Sumatra North Sumatra is expected to be a strength of the literacy culture of students so that it is not easily influenced by foreign cultures which are currently easily accessible to students. Researchers hope that the development of literacy books in schools will help improve student learning abilities.

\section{Research Methods}

This study uses a quantitative approach with research and development methods or research and development (R\&D). The development model used is the Borg and Gall model. This model consists of 6 stages, namely (1) preliminary survey, (2) product development, (3) product design, (4) design validation, (5) design improvement, and (6) final product. The population of this study were all students of class V at SD Kalam Kudus-2 Medan, amounting to 109 people and the research sample was class V Mikha, totaling 29 people. The sampling technique used in this research is purposive sampling technique, in which the purposive sampling technique the researcher determines himself the sample taken because of certain considerations. The form of the instrument in this study used a non-test instrument. This study uses two questionnaires. The questionnaire is related to the analysis of the needs of students and teachers and the second questionnaire is in the form of a Likert scale for the assessment of material experts and practitioners on the appropriateness of enrichment books to support the School Literacy Movement through fairy tales. Data analysis using descriptive qualitative. The data analysis conducted was to examine the needs of students and teachers, the stories used, and the validity sheet for expert testing. The analysis is continued with drawing conclusions based on the problems that are the focus of the research. 


\section{Result and Discussion}

\subsection{Result}

a. The Process of Developing a Literacy Reading Book with a Story of North Sumatra

This research on the development of literacy reading books follows the development steps of Borg and Gall. This research produces a limited trial product design in the form of a reading book. The development of this book uses 6 steps of development from 10 steps proposed by Borg and Gall.

This research development step is visualized as follows.

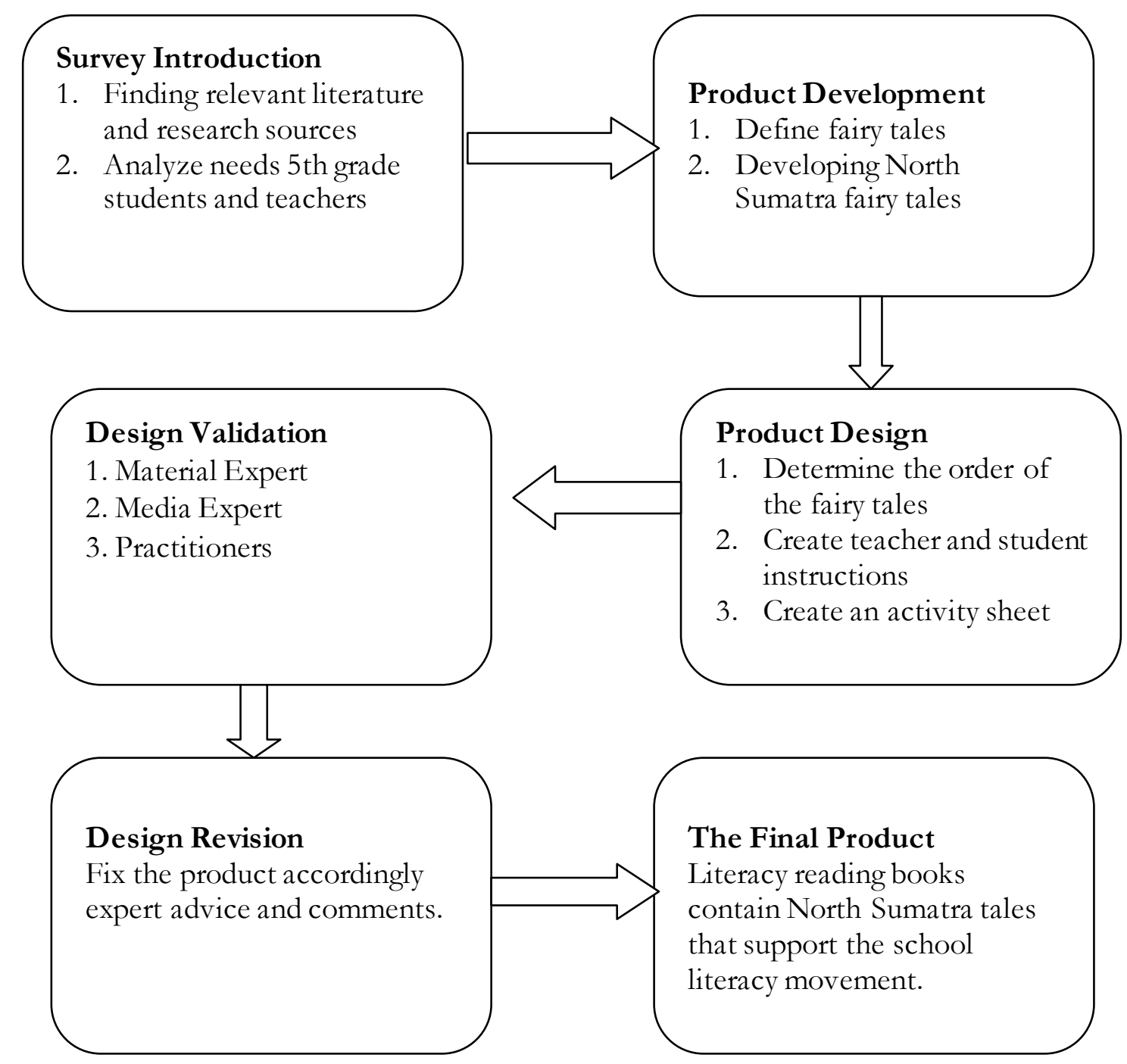

Figure. 1. Steps to Develop a Literacy Reading Book with Content North Sumatra Fairy Tales 
The process carried out in the development of this book uses the following steps. 1. Survey Introduction

The first step in this research is to analyze the teacher's knowledge of the literacy movement that has been implemented in schools. The analysis of teacher knowledge was carried out by distributing a questionnaire to two teachers at SD Kalam Kudus-2, Medan. The questionnaire outlines teachers' knowledge of the school literacy movement. Data analysis of teacher knowledge about literacy can be seen in table 1 below.

Tabel 1. Teacher Knowledge Data in the Implementation of the School Literacy

\begin{tabular}{|c|c|c|c|c|c|c|c|}
\hline \multirow{4}{*}{ No } & \\
\hline & \multirow{3}{*}{ Information } & \multicolumn{6}{|c|}{ Teacher Assessment } \\
\hline & & \multicolumn{2}{|c|}{ Yes } & \multicolumn{2}{|c|}{ Doubtful } & \multicolumn{2}{|c|}{ NO } \\
\hline & & Total & $\%$ & Total & $\%$ & Total & $\%$ \\
\hline 1. & $\begin{array}{l}\text { Introduction of government goals in } \\
\text { implementing literacy culture }\end{array}$ & 0 & 0 & 2 & $100 \%$ & 0 & 0 \\
\hline 2 & $\begin{array}{l}\text { The benefits Introduction of the school } \\
\text { literacy movement that has been } \\
\text { running }\end{array}$ & 0 & 0 & 2 & $100 \%$ & 0 & 0 \\
\hline 3 & $\begin{array}{l}\text { Literacy movement applications at } \\
\text { schools }\end{array}$ & 0 & 0 & 2 & $100 \%$ & 0 & 0 \\
\hline
\end{tabular}

The results of tracing the questionnaires that have been distributed, it is found that teachers have doubts in implementing literacy movements in schools. After analyzing the teacher's knowledge of the implementation of the literacy movement in schools, a needs analysis is then carried out. Literacy reading book needs analysis data can be seen in table 2 below :

Table 2. Data Analysis of Needs for Literacy Books Contained with Tales of North Sumatra

\begin{tabular}{|c|c|c|c|c|c|c|}
\hline \multirow{2}{*}{ No } & \multicolumn{2}{|c|}{ Types of Information } & \multirow{2}{*}{ Answer } & \multicolumn{4}{|c|}{ Frequency } \\
\cline { 4 - 7 } & & & Teacher & $\mathbf{\%}$ & Students & $\mathbf{\%}$ \\
\hline 1 & $\begin{array}{l}\text { Geting to know literacy books } \\
\text { that contain the wisdom of } \\
\text { North Sumatra }\end{array}$ & Yes & 2 & $100 \%$ & 0 & 0 \\
\cline { 4 - 7 } 2 & $\begin{array}{l}\text { Using literacy reading books } \\
\text { containing North Sumatra tales } \\
\text { when the school literacy } \\
\text { movement took place No }\end{array}$ & 0 & 0 & 29 & $100 \%$ \\
\hline & \begin{tabular}{l} 
Needing literacy reading books \\
with North Sumatra fairy tales \\
when the school literacy \\
\cline { 5 - 7 } \\
movement takes place
\end{tabular} & Yes & 2 & $100 \%$ & 29 & $100 \%$ \\
\hline
\end{tabular}

Tracing results from the questionnaires that have been distributed, it was found that $100 \%$ of teachers and students stated that they needed literacy reading books containing North Sumatra tales so that the literacy movement that runs was more varied and innovative.

1. Product Development

Product development includes the production of reading book components such as text, pictures, and practice questions. This also includes combining these elements so that they become integrated parts. 
Based on the analysis of the needs of teachers and students, the researchers concluded that reading books were needed that could add reading references for the sake of the literacy movement in schools. Through this reading book, North Sumatra wisdom culture will be introduced. In addition, this reading book also contains moral values that can be learned from each story. Here's a look at the cover image being developed.

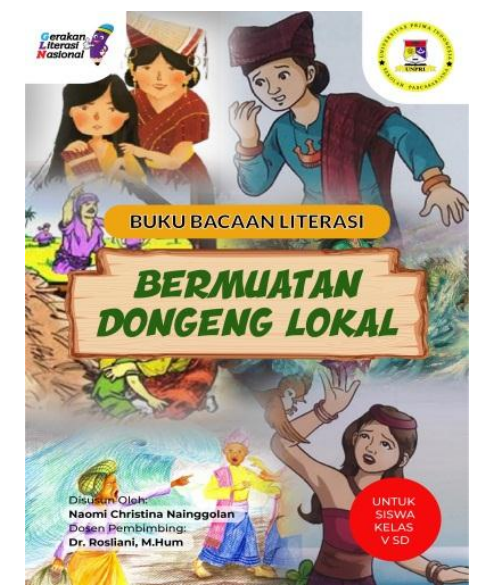

Figure 2. Cover of a Literacy Reading Book Contain of North Sumatra Fairy Tales

\section{Product Design}

At this stage the researchers carried out activities to design and design reading books to support the School Literacy Movement through fairy tales. The preparation of this book is in accordance with the correct and correct Indonesian Spelling (EBI). Good means in accordance with language courtesy, while true means in accordance with linguistic rules. The reading book containing North Sumatra fairy tales developed contains titles, instructions for the use of books (students and teachers), an introduction, a collection of North Sumatra stories, evaluations made at the end of each story, the moral values contained in each story, as well as reflections on the reading.

\section{Design Validation}

Design validation is a production process that is carried out by providing based on rational thinking. In validating the design of literacy book development to support the School Literacy Movement through fairy tales for elementary school students, it is carried out by experts in their fields. The design validation in this study was reviewed by media, material, and expert experts. This is done to obtain input and provide for improvement. The process of validating the design looks at several aspects of its feasibility, namely content, readability, presentation, and graphics.

a. The Data on the Validation Results of the Expert Team for Literacy Reading Book Materials Contained with North Sumatra Tales

Validation of the product is intended to determine the opinion of material experts on the feasibility of the content, the feasibility of presentation, and the language of the literacy reading book that contains the story.

Based on the results of the questionnaire assessment on the feasibility aspect of the content of the material that has been carried out by the validator, it is concluded that literacy books containing North Sumatra fairy tales have been developed "well" with a total average percentage of $82.69 \%$. 
b. Data from the Validation Results of the Expert Team for Literacy Reading Book Design with North Sumatra Fairy Tales

Learning design experts validate literacy reading books made by North Sumatra fairy tales on the aspects of book design (graphics). The validation of the learning design was carried out by Prof. Dr. Tien Rafida, M. Hum. who is a lecturer at UIN and L.J.K Sianipar, S.Si, M.Kom who is a teacher at Kalam Kudus School, Medan. The assessment on this design aspect is carried out to improve the quality of the appearance of the literacy reading books containing North Sumatra fairy tales that have been developed. The results of the validation of literacy reading books containing North Sumatra fairy tales by design experts concluded that the learning design developed was in the "very good" criteria with an average total presentation of $87.94 \%$.

c. The Results of Practitioners' Assessments (Indonesian Language Teachers) on Literacy Reading Books Contained with North Sumatra Fairy Tales

This study was also assessed by teachers involved in implementing the literacy movement. Teacher assessments were carried out by Farida L. Pasaribu, S.Pd. and Vricsilya Panjaitan, S.Pd.

The assessment of literacy reading books containing developed North Sumatra wisdom tales is carried out to obtain information about the quality of the products being developed. The results of the assessment are in the form of scores on parts of the learning that are in accordance with the current school literacy movement.

The results of the Indonesian language teachers show that literacy reading books containing the wisdom of North Sumatra are categorized as "very good" with an average total presentation of $98.9 \%$.

\section{Design Improvements}

After the literacy book design is validated through supervisors and experts, suggestions in the form of weaknesses will be corrected for the improvement of reading books.

a. Suggestions from Material Expert Validators on Reading Books Contained with North Sumatra Fairy Tales.

Based on the validation carried out by the material expert team on literacy reading books containing North Sumatra tales, suggestions / input were obtained both written and oral from the material expert team. The suggestions submitted are listed in table 3 below.

Tabel 3. Material Expert Validator Suggestions for Literacy Reading Books Contained with North Sumatra Fairy Tales

\begin{tabular}{|c|l|}
\hline No & \multicolumn{1}{|c|}{ Suggestion } \\
\hline 1 & The text of the story should not be too long \\
\hline 2 & Choose a fairy tale in a style that is easy for children to digest \\
\hline 3 & Put moral message points according to character education \\
\hline
\end{tabular}


b. Suggestions from Material Expert Validators on Reading Books Contained with North Sumatra Fairy Tales

Based on the validation carried out by the material expert team on literacy reading books containing the wisdom of North Sumatra, it was obtained suggestions / input both written and oral from the material expert team. The suggestions submitted are listed in table 4 below.

Tabel 4. Design Expert Validator Suggestions for Literacy Reading Books Contained with North Sumatra Fairy Tales

\begin{tabular}{|c|c|}
\hline No & \multicolumn{1}{|c|}{ Suggestion } \\
\hline 1 & The letter size on the cover must be corrected \\
\hline 2 & Place the image on the portion \\
\hline 3 & The illustration of the object image / character is reproduced \\
\hline
\end{tabular}

\section{Final Product}

The final product is a product that has been revised based on suggestions and criticism from experts. After going through the process, the researchers finally completed the product that had been developed based on the input that had been made. The resulting product is entitled "Literacy Reading Book Contains Tales of North Sumatra". After this, the product will be tested on a predetermined sample to determine the effectiveness of the product that has been developed.

\section{b. The effectiveness of literacy books containing North Sumatra fairy tales for fifth grade students at SD Kalam Kudus-2 Medan}

After the development process has been carried out by conducting validity tests on material experts, design experts and practitioners, this literacy reading book containing North Sumatra tales will be tested on both small field samples and limited field samples. This trial was carried out in their respective homes because of the conditions currently being experienced by the country, namely the Covid-19 pandemic. The researcher gave the product in PDF form to the children, then distributed the questionnaire by providing a link in the form of a google form. The following is done to determine the effectiveness of the books that have been developed.

1. Response Results of small field trials of literacy reading books based on the wisdom of North Sumatra wisdom

This study also conducted a small field trial which was carried out at SD Swasta Kalam Kudus-2 Medan on three grade V SD students. This is done to identify deficiencies in the product and obtain responses from students to products that have been developed. From the results of the small field trial assessment above, it can be concluded that the developed reading books are included in the "very good" criteria with an average percentage of $91.66 \%$.

2. Response Results of Limited Field Group Trials. Literacy Reading Books with North Sumatra Fairy Tales

This study also conducted field trials in the Kalam Kudus -2 Private Elementary School in Medan. Field trials were conducted on 29 students with high, medium and low abilities. Limited field trials produce data that will be used to find out how the product benefits students. The data on the response to the limited field trial group to the reading books that have been developed are included in the "very good" criteria with an average score percentage of $95 \%$. 


\subsection{Discussion}

The research discussion describes the research results that have been obtained. The discussion includes the process of developing literacy books containing North Sumatra tales and the effectiveness of literacy reading books containing North Sumatra tales for elementary school students in grade $\mathrm{V}$.

\section{a. Discussion of the Process of Developing a Literacy Reading Book with a Story of North Sumatra}

The first step in the process of developing literacy books is to conduct a field survey through an analysis of teachers' knowledge of literacy movements that have been implemented in schools. Through tracing results from distributed questionnaires, it was found that teachers had doubts about implementing literacy movements in schools. The teacher stated that they did not really find the benefits of the walking literacy movement because they did not have a benchmark for assessing the ongoing literacy movement. They have carried out literacy activities in class, which is 15 minutes before the teaching and learning activities take place, but after 15 minutes of the activity, the children immediately enter the learning process so it is not known to what extent the students understand the reading that has been read.

Based on table 4 on the results of the study, namely regarding the analysis of needs by teachers and students, it can be concluded that:

1. All teachers $(100 \%)$ stated that they were familiar with literacy reading books containing tales of North Sumatra, but it was found that all students $(100 \%)$ stated that they were not familiar with literacy reading books that contained stories of wisdom from North Sumatra.

2. Teachers and students do not use literacy books containing North Sumatra tales when the school literacy movement is taking place.

3. All teachers and students stated that they needed literacy reading books containing North Sumatra tales during the school literacy movement.

Based on the analysis of the needs of teachers and students above, it can be concluded that the development of literacy reading books is needed by teachers and students in the process of running the literacy movement to improve the quality of the ongoing school literacy movement. Furthermore, the researcher plans to develop literacy books in the form of literacy reading books containing North Sumatra wisdom tales that are adjusted to predetermined standards based on content feasibility, language assessment, and the design of the reading book.

Aspects that are used as material for revising the product include components of presentation, language, feasibility, and book graphic. These aspects are used to produce products that are suitable for use by fifth grade elementary school students during literacy activities. The stages taken in product development include:

1. Validation of material experts and learning designs;

2. Expert validation analysis of material and learning design;

3. Revision;

4. Limited field trials;

5. Analysis of results of limited field trials;

6. Revision II;

7. The final product. 


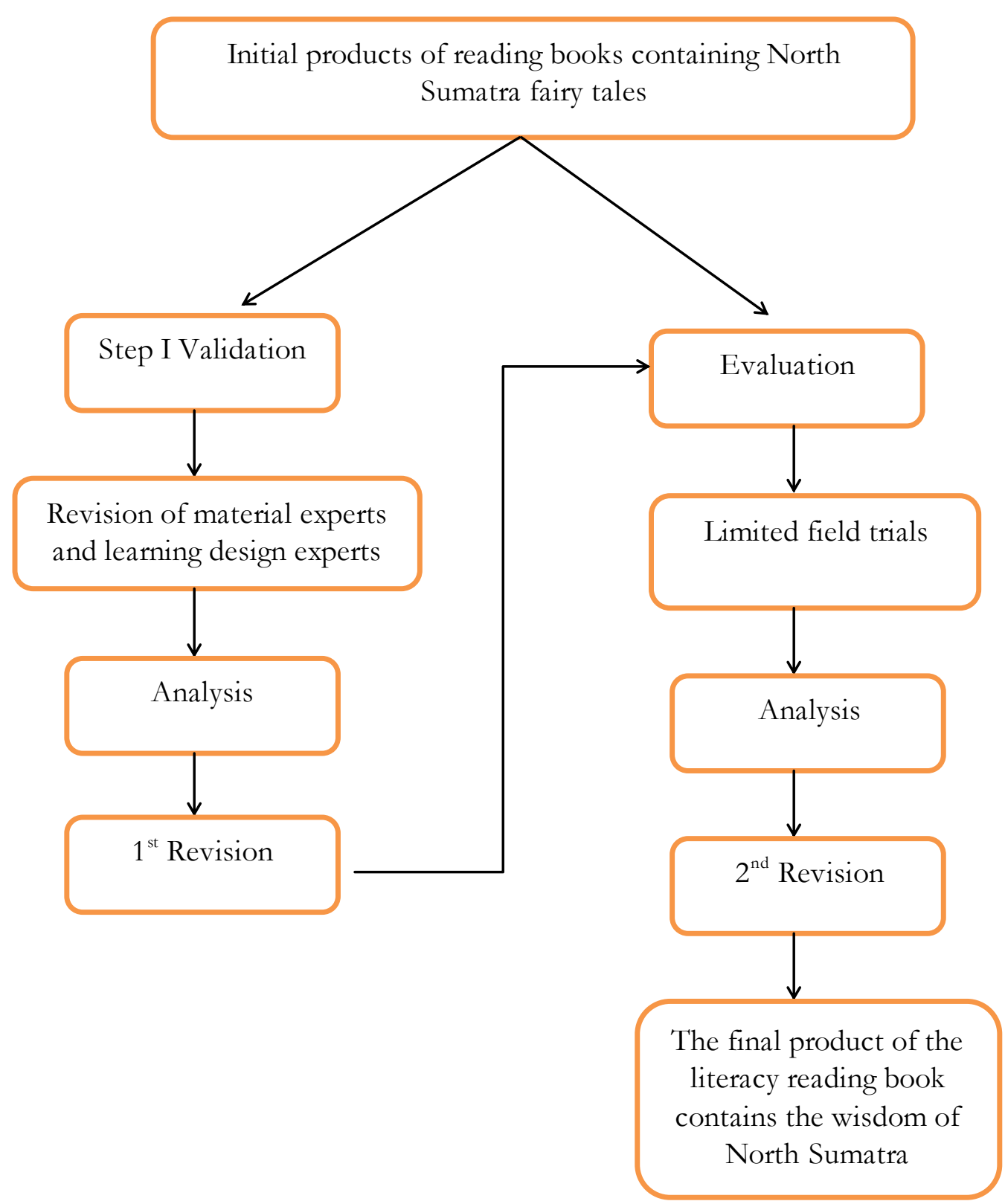

Figure 3. The Stages of Developing a Literacy Reading Book Containing the Wisdom of North Sumatra Tales

The first validation is given to the material expert. Based on the material expert's assessment, the literacy reading book variables have a very good average value. The material expert assessed that literacy reading books containing North Sumatra wisdom tales for grade V SD Private Kalam Kudus-2 Medan that were developed had content feasibility with an average score percentage of $82.69 \%$ with the criteria of "good". Based on this average score, it can be seen that literacy reading books that have been developed can meet the needs of the literacy movement in schools. The results of the average percentage of the content and presentation feasibility aspects of the existing assessment components based on the suitability of the content, material presentation techniques and language presentation can be seen in table 5 below. 
Tabel 5. Evaluation of Material Experts on the Appropriateness of Content and Presentation

\begin{tabular}{|c|l|c|c|}
\hline No & \multicolumn{1}{|c|}{$\begin{array}{c}\text { Sub-Section Component } \\
\text { Assessment }\end{array}$} & Average Score & Criteria \\
\hline 1 & Content suitability & $83,33 \%$ & $\mathrm{~B}$ \\
\hline 2 & Material Presentation Techniques & $82,5 \%$ & $\mathrm{~B}$ \\
\hline 3 & Presentation of Language & $82,5 \%$ & $\mathrm{~B}$ \\
\hline \multicolumn{2}{|c|}{ AverageAmount } & $82,69 \%$ & $\mathrm{~B}$ \\
\hline
\end{tabular}

From the detailed results of each sub-component above, the results of the validation of literacy reading books containing North Sumatra fairy tales carried out by material experts were declared "good". The results of the validation include 3 aspects of assessment, namely content feasibility, presentation feasibility, language assessment. The results of the assessment of the content feasibility aspect were declared good with an average total percentage of $83.33 \%$. The assessment of material feasibility was declared "good" with a total average percentage of $82.5 \%$, and the aspect of language assessment was declared "good" with a total average percentage of $82.5 \%$.

After the validation was carried out by the material expert team, then the validation was also carried out from the learning design expert team. The design expert assessed that the literacy supplement book containing the wisdom of North Sumatra for grade V SD Kalam Kudus-2 Medan which was developed was feasible with an average score percentage of $87.94 \%$. The average percentage result is obtained based on the sub-components of the assessment in the form of book cover design with cover layout components, cover typography, cover illustrations and book design sub-components with layout components, typography and content illustrations. This can be seen in table 6 below.

Tabel 6. Assessment from Design Experts of Supplementary Literacy Books Contained with the Wisdom of North Sumatra Tales

\begin{tabular}{|c|l|c|c|}
\hline No & $\begin{array}{c}\text { Sub-section of the Assessment } \\
\text { Component }\end{array}$ & Average Score & Criteria \\
\hline 1 & Book Size & $100 \%$ & $\mathrm{~A}$ \\
\hline 2 & Cover layout & $84,4 \%$ & $\mathrm{~B}$ \\
\hline 3 & Cover typography & $84,4 \%$ & $\mathrm{~B}$ \\
\hline 4 & Cover Illustration & $87,5 \%$ & $\mathrm{~B}$ \\
\hline 5 & Content layout & $89,3 \%$ & $\mathrm{~B}$ \\
\hline 6 & Typographic Content & $97,5 \%$ & $\mathrm{~A}$ \\
\hline 7 & Content Illustration & $94,4 \%$ & $\mathrm{~A}$ \\
\hline \multicolumn{2}{|c|}{ Average Amount } & $87,94 \%$ & $\mathrm{~B}$ \\
\hline
\end{tabular}

From the detailed results of each sub-component above, the result of the validation of literacy reading books containing North Sumatra fairy tales by design experts was declared "good". The validation results include 7 aspects of assessment, namely book size, book layout on book cover design, cover typography on book cover design, cover illustration on book cover design, layout on book design, typography on book design, and illustration of contents on design book. The results of the assessment of the book size aspect are stated very well with an average total percentage of $100 \%$. The evaluation of the book layout aspects on the book cover design is declared "good" with an average total percentage of $84.4 \%$, the cover typography aspect of the book cover design is declared "good" with an average total percentage of $84.4 \%$, the cover illustration aspect There is a book cover design stated as "very 
good" with a total average percentage of $87.5 \%$, the layout aspect of the book design is stated "very good" with a total average percentage of $89.3 \%$, the typographic aspect of the book design is stated "Very good" with an average total percentage of $97.5 \%$, and the content illustration aspect of the book design was declared "very good" with an average total percentage of $94.4 \%$.

\section{b. Discussion on the Effectiveness of the Literacy Book with North Sumatra Tales for Class V Students at SD Kalam Kudus-2 Medan}

To find out how the students responded to literacy reading books containing the wisdom of North Sumatra, a small field trial and a group trial were conducted. It was found that the results of small field trials on literacy reading books that had been developed showed an average percentage of $91.66 \%$ with "very good" criteria. Small field trials were carried out to find out students' initial responses and identify product deficiencies of the products to be developed before the limited field trial was carried out.

The average percentage results are obtained based on assessment indicators in the form of material, language, design and interest in the literacy supplement book developed can be seen in the following table 4:12.

Tabel 7. Percentage of Small Field Trial Scores Acquisition of Literacy Reading Books Contained with Fairy Tales of North Sumatra

\begin{tabular}{|l|l|c|c|}
\hline No & \multicolumn{1}{|c|}{ Assessment Indicators } & Average score & Criteria \\
\hline 1 & Contents & $80 \%$ & $\mathrm{~B}$ \\
\hline 2 & Language & $100 \%$ & $\mathrm{~A}$ \\
\hline 3 & Design & $93,75 \%$ & $\mathrm{~A}$ \\
\hline 4 & Interest & $91,66 \%$ & $\mathrm{~A}$ \\
\hline \multicolumn{2}{|l|}{ Average Amount } & 91,66 & $\mathrm{~A}$ \\
\hline
\end{tabular}

Based on the results of the average percentage shown above, it is found that the assessment of the content in literacy reading books is $80 \%$ with the criteria of "good", the assessment of the language in literacy reading books is $100 \%$ with the criteria "very good", the assessment of the book design in literacy reading books amounted to $93.75 \%$ with the criteria "very good" and an assessment of student interest in literacy reading books by $91.66 \%$ with the criteria "very good". This means that literacy reading books containing North Sumatra wisdom tales that have been developed are in accordance with the needs of students.

The overall average percentage result is $91.66 \%$ with "very good" criteria, so there is no need for revisions to the literacy reading books that have been developed so that they can be continued in limited field trials.

After a limited field trial was carried out, the results of a limited field trial on literacy supplement books that had been developed showed a percentage of $95 \%$ with the criteria of "very good". This means that literacy books containing North Sumatra fairy tales that have been developed meet the demands of the literacy movement in schools. This limited field trial assessment is the final stage of the trial of literacy supplement book products containing North Sumatra wisdom tales in grade V SD. The average percentage results are obtained based on assessment indicators in the form of content, language, design and student interest in literacy reading books that have been developed can be seen in the following table 8 . 
Tabel 8. Percentage of Limited Field Trial Scores Acquisition on Literacy Reading Books Contained with Fairy Tales of North Sumatra

\begin{tabular}{|l|l|c|c|}
\hline No & Assessment Indicators & Average score & Criteria \\
\hline 1 & Contents & $94,64 \%$ & $\mathrm{~A}$ \\
\hline 2 & Language & $93,75 \%$ & $\mathrm{~A}$ \\
\hline 3 & Design & $95,22 \%$ & $\mathrm{~A}$ \\
\hline 4 & Interest & $96 \%$ & $\mathrm{~A}$ \\
\hline \multicolumn{2}{|l|}{ Average Amount } & $95 \%$ & $\mathrm{~A}$ \\
\hline
\end{tabular}

Based on the details of each component above, it is found that the assessment of the content in literacy reading books has a percentage of $94.64 \%$ with the criteria the assessment of language in literacy reading books has a percentage of $93.75 \%$ with the criteria "very good" , the assessment of book design in literacy reading books is $95.22 \%$ with the criteria "very good" and the assessment of student interest in literacy reading books has a percentage of $96 \%$ with the criteria "very good". So that the overall average percentage of the limited field test results is $95 \%$ with the criteria "very good".

Based on the discussion of the research findings that have been described above, it can be concluded that the findings of literacy reading books containing North Sumatra tales for feasibility of use are declared feasible because the validation of teachers, material experts and instructional media designs on average are in the "very good" category. Likewise, the results of student trials are in the "very good" category.

According to their respective abilities independently, learning to be more focused and not causing boredom because it is equipped with North Sumatra tales in North Sumatra. contains illustrations and pictures that are attractive to children, and contains interesting questions to see student absorption "very good".

\section{Conclusion}

Based on the research findings above, it can be concluded as follows. First, the process of developing a literacy reading book with North Sumatra fairy tales follows the development steps of Borg and Gall. This model consists of 6 stages, namely (1) preliminary survey, (2) product development, (3) product design, (4) design validation, (5) design improvement, and (6) final product. This research produces a product in the form of literacy reading books containing North Sumatra fairy tales. The book, which was developed under the name Literacy Reading Book with North Sumatra Fairy Tales, is equipped with teacher and student guides, tales from North Sumatra, and practice questions. The book developed is feasible and ready to be implemented in terms of graphics, presentation, material / content, and language. This has gone through a revision process obtained from material experts, learning design experts, and practitioners who are involved in the school literacy movement.

Second, the results of small field trials are stated to be "very good" with a total average percentage of $91.66 \%$. The results of limited field trials were stated to be "very good" with a total average percentage of $95 \%$. Based on the results of these trials, it was stated that this literacy reading book was declared very suitable for use by fifth grade elementary school students to support the school literacy movement, because all assessment results were in the "very good" category. 


\section{References}

Abidin dkk. 2017. Pembelajaran Literasi. Jakarta : Bumi Aksara.

Bu'ulolo, Y. 2019. Pengembangan Bahan Ajar Menulis Cerpen Berbasis Literasi Media Siswa Kelas XI SMA Negeri 1 Lolomatua. Tesis. Medan: Universitas Negeri Medan.

Depdiknas. 2008. Panduan Pengembangan Bahan Ajar. Jakarta : Direktorat Pembinaan Sekolah Dasar.

Direktorat Jenderal Pendidikan Dasar dan Menengah Kementrian Pendidikan dan Kebudayaan.2015. Buku Saku Gerakan Literasi Sekolah. Jakarta: Satgas

Firman. 2007. Analisis Literasi Sains Berdasarkan Hasil PISA Nasional 2006. Jakarta : Pusat Penilaian Pendidikan Balitbang Depdiknas.

Hartono. 2011. Metodologi Penelitian. Pekan Baru : Zanafa Publishing.

Hartati, T. 2016. Multimedia Dalam Pengembangan Literasi di Sekolah Dasar Terpencil di Jawa Barat. Jurnal Edutech, Volume 15 (3) hal 301-310.

Kucer, S. B. 2014. Dimensions of Literacy. New York : Routledge.

Lestariningsih, N dan Sudirman S. 2016. Pengembangan Bahan Ajar Tematik-Integratif Berbasis Kearifan Sumatera Utara Untuk Meningkatkan Karakter Peduli dan Tanggung Jawab. Jurnal Pendidikan Karakter. Tahun VII Nomor 1 April 2017.

Mursyidi, et al., (2019). The EffortofIslamic Boarding SchoolLeaders'to Improve the Potential of StudentsinReading Arabic Books(A Study in Dayah Raudhatun Hasanah Namploh Manyang, Samalanga Sub-District, Bireuen District). Britain International of Linguistics, Arts andEducation(BIoLAE)Journal Vol.1 (2): 232-241.

Nurdiyanti \& Suryanto. 2010. Pembelajaran Literasi Mata Pelajaran Bahasa Indonesia Pada Siswa Kelas V Sekolah Dasar. Tesis. Surakarta : FKIP UNS.

Oktaviani dkk. 2017. Menggagas Kajian Kearifan Budaya Sumatera Utara di Sekolah Dasar Melalyu Gerakan Literasi Sekolah. FKIP Universitar Muria Kudus : Prosiding Seminar Nasional.

Pangesti, dkk. 2016. Desain Induk Gerakan Literasi Sekolah. Jakarta: Direktorat Jenderal Pendidikan Dasar dan Menengah Kementerian Pendidikan dan Kebudayaan.

Pusat Perbukuan Departemen Pendidikan Nasional. 2008. Pedoman Menulis Buku Teks. Jakarta: Pusat Perbukuan Departemen Pendidikan Nasional.

Rahayu, Triwati. 2016. Penumbuban Budi Pekerti Melalui Gerakan Literasi Sekolah.

The Progressive and Fun Education Seminar. Onlie: publikasiilmiah.ums.ac.id

Rustaman, N. (2004). Literasi Sains Anak Indonesia 2000, 2003. [Online]: Tersedia: literasi_sains \%20anak\%20Indonesia\%20 (5 Jan 2015)

Sarumpaet, Riris K. Toha. 2009. Pedoman Penelitian Satra Anak. Jakarta: Yayasan Pustaka Obor Indonesia.

Setiyadi, Bambang. 2006. Metode Penelitian untuk Pengajaran Bahasa Asing. Yogyakarta: Bumi Aksara Ilmu.

Setyawan, Ibnu Aji. 2018. Kupas Tuntas Jenis dan Pengertian Literasi. Online: gurudigital.id. Gerakan Literasi Sekolah.

Sibarani, R. 2014. Kearifan Sumatera Utara. Jakarta : Asosiasi Tradisi Lisan.

Sudjana, Nana dan Ibrahim. 2009. Penelitian dan Penilaian Pendidikan. Bandung: Sinar Baru Algensindo.

Sugiyono. 2013. Metode Penelitian Pendidikan. Bandung: Alfabeta.

Syakur, A., Azis, R., and Sukarsih. (2020). Developing Reading Learning Model toIncrease Reading Skill forAnimal Husbandry Students in Higher Education. Britain International of Linguistics, Arts andEducation(BIoLAE) Journal Vol. 2 (1): 484-493. 